\title{
THE GENERAL PRINCIPLES OF CIVIL LAW OF THE PRC: ITS BIRTH, CHARACTERISTICS, AND ROLE
}

\author{
Tong Rou* \\ Translated by Jonathan K. Ocko
}

I

INTRODUCTION

Civil law ${ }^{1}$ is the basic (jiben) law used to regulate relations in a commodity economy. In the legal system of the People's Republic of China ("PRC") civil law occupies a critical position. Chinese law is divided into three levels: fundamental (genben) law, basic (jiben) law, and specifically enacted (danxing) law. The fundamental law is the Constitution, which has the greatest legal effect in the legal system; basic law is law which regulates certain aspects of social relations, and its effect is subordinate to that of the Constitution but superior to special law. Civil law is a basic law which regulates the property and personal relations between equal subjects and assumes the leading role toward the various sorts of special enactments (danxing fagui) and economic regulations (jingii fagui) in the economic sector.

On April 12, 1986, the Fourth Session of the Sixth National People's Congress passed the General Principles of Civil Law of the Chinese People's Republic. This not only legislatively established the central position of civil law in the Chinese legal system, but it also symbolized that the construction of Chinese law and democracy had entered a new stage. This article is an exposition of the emergence, characteristics, and role of the General Principles of Civil Law in the PRC.

II

\section{The Birth of the General Principles}

The General Principles is the fruit of thirty years of civil legislation in China. China's civil legislation, like China's economic development, has followed a tortuous path. This process of the development of the General Principles can essentially be divided into three stages.

\footnotetext{
Copyright $@ 1989$ by Law and Contemporary Problems

* Director, China Law Society; General Secretary, China Civil and Economic Law Research Association; Professor of Civil Law, Department of Law, People's University, Doctoral Tutor.

1. Throughout this article, civil law refers generally to those legal norms that regulate property and personal non-property relationships. See definition of minfa (civil law) in Faxue cidian (LAW Dictionary) 204 (1989). See also Tong Rou et al., Minfa gailun (General Discussion of Civil LAW) 1-20 (1982).
} 
A. Stage One: From the Early Period of the Establishment of the Country to the Completion of the First Five-Year Plan (1949-1956)

After the establishment, in October 1949, of the PRC, the country was faced with the arduous tasks of restoration of the national economy, socialist reform, and the initiation of large-scale economic construction. In response to these needs, the nation employed civil law methods to regulate social economic relations. The People's Government formulated and disseminated a set of civil enactments. For instance, to affirm and protect the right of property ownership, it promulgated and put into force the Land Reform Law of the PRC and the Method for Handling Debts in New District Villages; to embody the nation's policy toward the use, control, and reform of the private capitalist economy, the government issued the Temporary Regulations for Privately Managed Enterprises. Legal forms were used to confirm the legality of various types of privately managed enterprises. In order to regulate property relations, appropriate civil law standards were promulgated for: purchase and sale of goods and materials, supply and marketing, processing contracts, basic construction contracting, circulation of technology, building rental, transport of goods and passengers, storage, consignment, property and personal insurance, credit, settling accounts, savings, etc.

Moreover, on April 30, 1950, another law that also belongs within the scope of civil legislation was published, the Marriage Law. Its promulgation marked the replacement of several thousand years of a feudal marriage system with the new system of the people's democracy. It clearly propounded the abandonment of the feudal customs of coercive arranged marriages, gender inequality, and disdain for the interests of women and children. All of this important civil legislation played a vital role in terms of regulating civil relationships, in protecting the lawful rights of citizens, and in stabilizing the socioeconomic order.

At this stage, in order to complete the socialist reformation of agriculture, handicraft industry, and capitalist industry and commerce, and to realize the profound transformation of the means of production from private ownership to collective ownership, there was a demand not only for the formulation of many special civil law enactments but also for the formulation of a civil code that could reflect the socialist economics, thought, culture, and morality of the new China. Therefore, in the winter of 1954 the Standing Committee of the National People's Congress organized a civil law drafting group and charged it with drafting a civil code. Based on an integration of the borrowed experiences of the Soviet Union's construction of a legal system and our own experience in China, the completed first draft was made up of four parts: general principles, ownership, obligation, and inheritance. Subsequent political movements, however, interrupted this work. 
B. Second Stage: From the Beginning of the Construction of Socialism to the Smashing of "The Gang of Four" (1956-1976)

After the socialist transformation was basically completed, China began to shift into full-scale socialism. As was pointed out when the Eighth Congress of the Chinese Communist Party convened in September 1956, the chief task was for the people to concentrate their strength to develop society's productivity, to realize the country's industrialization, and to steadily satisfy their material and cultural demands, all of which were increasing daily. But, beginning in 1958, because objective economic laws, especially the law of prices, were overlooked, the "Great Leap Forward" and the rural "People's Communes" movements were rashly initiated, thereby causing rampant and still extant leftist mistakes in the socialist economy. ${ }^{2}$ In the midst of economic construction, this exaggerated communism and the accompanying confused and arbitrary directions caused collective property and the legitimate property rights of individual citizens to be violated as the rule of no compensation replaced the principles of equal value and mutual benefit that should characterize economic contact between civil subjects. Under the influence of the ideological trend of legal nihilism, civil legislation fell into desuetude. In 1960 the party and the state began to correct the errors of this "left" tendency and resolved in regard to the national economy to carry out the principles of "regulation (tiaozheng), consolidation (gonggu), strengthening (chongshi), and enhancement (tigao)." In these circumstances, the Party and state formulated a series of civil policies and enactments such as Work Regulations for Rural People's Communes (Draft), Work Rules for State-Run Industrial Enterprises (Draft), Temporary Regulations for the Protection and Administration of Cultural Artifacts, Provisional Method for the Management of the Registration of Industrial and Commercial Enterprises, Trademark Administration Regulations, and Rules for Rewards for Technical Improvements. This series of civil enactments and regulations, which were formulated and put into effect in the midst of the correction of the national economy, played a vital role in expunging the harm that the radical policies of the "left" had created in the economic sector, in overcoming the economic difficulties of that time, and in recovering and developing the national economy.

2. Speical Editor's note: The Great Leap Forward of 1958 to 1960, of which the rural People's Communes movement was a part, sought to achieve an economic breakthrough and political mobilization which would allow China not only to leap beyond the industrial levels of Western European nations but also to leap from its just completed socialist revolution directly into communism. The People's Communes were created by aggregating smaller agricultural producers' cooperatives into larger units which had a more collective character and combined political and economic administration. The guiding policies of this period, many of which resurfaced during the Cultural Revolution (1966-1976), have been subsequently labelled "leftist." They included mass mobilization, preference for large-scale social organizations as closer to true communism, persistence of the language of class struggle, emphasis on "redness" or correct ideology over expertise, and insistence on the ability of the human will to overcome objective circumstances. See $M$. Meisner, Mao's China 204-54 (1977), for a general discussion, and R. Mac Farquhar, The Origins of the Cultural Revolution: 2: The Great leap Forward 1-4, 326-36. For an early criticism by Lenin of "leap" thinking see A. Chan et al., Chen Village 169-85 (1984). 
Following the recuperation and development of the national economy, the work of drafting the Civil Code began once again. In the latter half of 1962 , the Standing Committee of the National People's Congress ("NPC") organized anew the drafting work, and in 1964 formally put forward the Provisional Draft of the Civil Code of the PRC. This draft tried to escape from the premises of the Soviet legislative style and integrate the experience of China's economic construction and judicial practice in order to formulate a civil code with Chinese characteristics. But because of the limitations of the economic situation, the drafting work at that time was still influenced by the ideological trend of the "left." Using beneficial foreign legislative experience as a reference was overlooked, so that when completed the Provisional Draft lacked the force of normative law. Subsequently, following the beginning of the Cultural Revolution, the work of drafting a civil code was again forcibly halted, and in the ten years of chaos which followed, not only was civil legislation placed in a suspended state, it also suffered serious injury.

\section{Stage Three: From the Smashing of the "Gang of Four"3 to the}

Promulgation of the General Principles (1976-1986)

After the "Gang of Four" was smashed in October 1976, the PRC entered a new period of historical development. In particular, after the Third Plenum of the Eleventh Central Committee was convened, and after the shift in the emphasis of the country's goals to socialist modernization and construction, and together with the formulation and implementation of the policies of reform, the opening of the PRC to the outside and the invigorated renewal of socialist legal construction was emphasized and China's civil legislation entered a new period of development. Large numbers of civil enactments were continuously issued and put into effect such as those promulgated by the standing committee of the NPC: the Economic Contract Law, the Inheritance Law, the Mineral Resource Law, the Foreign Economic Contract Law, the Joint Venture Law, the Trademark Law, and the Patent Law. The State Council also promulgated special enactments: sales contract regulations for industrial and mineral products, sales contract regulations for agricultural side-line production, loan contract regulations, contract regulations for contract processing, regulations for the control of urban private housing, regulations for property insurance contracts, architectural engineering responsibility contracts, regulations for invention rewards, regulations for rewards for work in natural sciences, and so forth.

In the process of invigorating the domestic scene and opening to the outside, the formulation of an appropriate civil code was an urgent need. So,

3. Special Editor's note: The Gang of Four was composed of Mao Zedong's wife, Jiang Qing, and three of her minions-Wang Hongwen, Zhang Chunqiao, and Yao Wenyuan-previously lowerlevel political operatives who rose to national power under her aegis and helped shape the direction of the Cultural Revolution (1966-1976). Upon Mao's death in September 1976, the Four were arrested by Mao's successor in an action that is called "the smashing of the Gang of Four." On the Cultural Revolution, see M. Meisner, supra note 2, at 309-81, and H. Lee, The Politics of the Cultural Revolution (1978). 
in October 1979, the Law Committee of the Standing Committee of the NPC specially organized the civil code small drafting group to begin the work of drafting a civil code for the third time. After three years of diligent labor, the group produced a fourth draft of the Civil Code in 1982. Because of the breadth of the civil law's scope and the complexity of its contents, and also because the economic reforms were still new and concrete social experience was relatively meager, conditions for working out a complete civil code were not yet ripe. Under these circumstances, the NPC Standing Committee resolved, on the basis of what was needed and what was possible, first to take from the Civil Code those parts that were more urgent and relatively more mature and make them separate laws. So through several years of hard work, the PRC continued to formulate certain key, independent civil legislation, such as the aforementioned Economic Contract Law, Foreign Economic Contract Law, Patent Law, Trademark Law, and Inheritance Law. These were of great use in perfecting civil legislation and regulating relevant civil relations. Still there were a number of fundamental questions, such as the object (duixiang) of civil law's regulation, the basic principles of civil law, the position in civil law of the citizen and the legal person, civil juristic acts, the rights of civil agency, obligations, and periods of limitation, that still lacked legal enactment and caused civil activities and civil judicial work to lack the necessary legal basis.

During these last several years, China's legislative and judicial practice and the reform of the urban economic structure have both accumulated rich experience. It is not only necessary but also possible for the state's legislative organs to make a number of enactments to deal with common problems in civil activities. But considering that the urban economic system's reform has just begun and that agricultural economic reform is deepening, there are many questions that are still unclear. Therefore, the moment to enact a complete civil code is still not propitious. In light of the above, the legal working committee of the NPC's Standing Committee, together with the Supreme People's Court and other specialists, summed up the practical experience of reform, opening, and invigoration, along with the practical experience of the courts in handling civil matters and economic cases on the basis of the draft of the civil law. The Standing Committee broadly solicited opinions and made repeated revisions, before it finally brought before the NPC for debate and passage a document with clearly Chinese characteristics, the General Principles of the Civil Law.

The resolution concerning reform of the economic system which was passed in October 1984 at the Third Plenum of the Twelfth Party Central Committee pointed out that the PRC's economy is a planned socialist commodity economy with socialist public ownership as its base. Responding to this need, our country has quickened the pace of economic reform with the city as the key. The General Principles' promulgation and implementation indubitably provide a legal standard and guarantor for the quickening of this pace. But because economic life and social relations are so richly varied and 
the General Principles is insufficient, we still need to formulate several supplementary enactments. Accordingly in the seventh five-year plan a series of discrete civil enactments will be promulgated: the Technology Contract Law, the Maritime Law, the Company Law, and a Law on Negotiable Instruments. One may predict that during the seventh five-year plan, a large quantity of civil law adapted to reform, opening, and invigoration will appear.

\section{III}

\section{Chief Characteristics of the General Principles}

Produced on the foundation of a summation of the more than thirty years of practical experience acquired in civil legislation and civil adjudication since the founding of the PRC, and produced in response to the needs of the reform of China's economic system and the development of its socialist commodities economy, the General Principles contains clear-cut Chinese characteristics. Four of the chief ones are discussed below.

\section{A. The Object of the Civil Law's Regulation and the Style of Legislation}

Civil legislation is intimately tied to a society's commodity relations. That is, the civil law reflects social commodities relations. The norms of the civil law are the expression in legal form of the conditions of a society's economic life. As Chinese socialist civil legislation, the General Principles reflects the demands of socialist commodities relations. Speaking in terms of its characteristic essence and leading aspect, the object of regulation is socialist commodity relations or, in other words, horizontal property and economic relations. Article 2 of the General Principles stipulates: "The civil law of the People's Republic of China regulates property relations and personal relations between subjects of equal status-between citizens, between legal persons, and between citizens and legal persons." This stipulation is an objective reflection of our socialist commodities relations, and it is a stipulation that has not come easily.

Since 1949 , in order to repair the war damage inflicted on the national economy and to transform the semi-colonial and semi-feudal economic system, and in order to smash imperialism's economic blockade of our country, the Party and the state, in addition to implementing a series of revolutionary reforms in the ownership of the means of production, had to adopt administrative methods of centralized management to direct the economy so that the national economy would develop rapidly, thereby creating the preconditions necessary for large-scale socialist economic construction. However, owing to our insufficient knowledge about a highly developed commodities economy, a stage of development that cannot be skipped in the progression toward an ideal state, we went so far as to mistake many of the measures necessary in the development of a socialist commodities economy for capitalism. Consequently not only was there no correction of the problem of centralization, but gradual development also became a sort of ossified form not suited to the development demands of socialist productivity. 
In a management system that overlooked the commodities economy and the law of value, the role of civil law in the economy was of course sharply weakened.

After the Third Plenum of the Eleventh Central Committee (October 1978) affirmed the policy of opening to the outside and invigorating the domestic economy, the villages implemented a system of contracting management responsibility. Many sorts of management forms appeared, and the villages gradually made the transition from self-sufficiency or half selfsufficiency toward a commodities economy. In the cities, with the simplification of administration and the devolution of authority as the heart of the reform, initial results have been achieved. At the Third Plenum of the Twelfth Central Committee, a resolution concerning reform of the economic system was passed which clearly pointed out that our socialist economy is "a planned commodities economy on a foundation of public ownership." Moreover, it pointed out the need to accelerate the reform of the economic system with the city as the key, the duty to vigorously develop the socialist commodity economy, and, in accord with these two points, the need to rapidly complete the legal system that would regulate the activities of the commodity economy. This last in turn became the urgent task of the legislative bodies.

Practice has proven that civil enactment is an important condition for stabilizing and developing commodity relations. It is a key standard for regulating the planned commodity relations that are taking shape on the foundation of the system of public ownership. Only with assistance from a civil law characterized by equality and equal value can we establish order in the socialist commodity economy, effectively prevent the defects that appear in commodity economies in capitalist societies, and cause the commodities economy to develop smoothly under the plan along the path of socialism. Article 2 of the General Principles provides for property relations between equal subjects. Speaking in terms of its essence, the relationship between ownership and the flow of commodities, the civil law is the legislative embodiment of the situation and summation of our commodities economy.

Article 2's stipulation considered the actual state of the development of horizontal economic ties, summed up the new circumstances of reform, opening, and invigoration as well as new problems and experiences, and embodied two prime characteristics of the civil law: First, a significant part of the civil law reflects in legal form the relationships between the commodities economy and the equality of the status and rights of participants in the exchange of commodities, and the quality of the legal status and rights of participants in civil affairs; second, the civil law chiefly regulates the property relations of equal subjects, that is horizontal property and economic relations. Relations that are not between equal subjects do not belong to the regulatory scope of the civil law. In accord with these two principles, the General Principles stipulated what constitute the core subjects of civil law: ownership, obligations, and contract. It also coordinates these three systems and plays the main role in the systems of legal acts, object, agency, and periods of 
limitation. Besides this, in order to protect the personal relations of citizens and legal persons, it also stipulates the right of citizens to name, reputation, their personal likeness, their right of life and health, and the legal person's right to name, reputation, and so forth. Considered from the legislative viewpoint, the scope of civil legislation also encompasses the systems of marriage, inheritance, and the results of intellectual effort.

The legislative style of the General Principles also possesses distinctly Chinese characteristics. Legislative style means the forms by which civil legal norms are compiled. Looking at it in terms of the rest of the world, England, the United States, and other common law countries do not have a written civil code. Civil law norms are dispersed in a mass of separate law and a vast sea of case law. Countries with the Continental system often establish a written civil code. Socialist countries also have enacted their own civil codes. In terms of civil code style, these codes generally include two parts: a general principles (tongze) section and a section of specific provisions (fenze). The general principles are concerned with provisions applied commonly to various sorts of civil relations such as the subject of civil relations, juristic acts, agency, periods of limitation, and so forth. The specific provisions regulate various sorts of concrete civil relations such as ownership, obligations, inheritance, and compensation for injury. Yet, since the conditions are not yet ripe for us to establish a complete civil code and since we have recently promulgated a series of important independent civil enactments, we have adopted the general principles (tongze) form in our civil legislation. This form contains not only general provisions but also some specific ones. It has not been limited by the traditional civil law legislative style of general and specific provisions. Moreover, its stipulations apply to those prior separate civil laws which continue to have force. Therefore, the legislative style of the General Principles is an innovation in the history of civil legislation, a product of the unique historical circumstances of the reform of our economic system and also suitable to China's situation.

\section{B. The General Principles' Establishment of a Regulatory System of Economic Law}

Economic law's regulatory system refers to the regulation of economic relations by the adoption of various legal forms, thereby achieving the goal of establishing and protecting an economic order that is beneficial to the ruling class. In a country with public ownership, there exist two dissimilar structures of economic regulation. One adopts a regulatory system of "departmental (bumen) economic law," takes public ownership as the base with the plan as the core, and uses the centralized economic part of the law to adjust economic relations between socialist organizations. This type of system of regulation by economic law, found in post-war Czechoslovakia and East Germany, requires the intervention of the state plan and either denies or deprecates the status of the enterprise legal person. Therefore it is adapted to centralized forms of economic control. The second type, represented by post-war Hungary and 
Poland, adopts a regulatory structure of "civil law-economic law." This type of structure recognizes the status of the enterprise legal person and insists on the independent rights, duties, and responsibilities of the enterprise in civil activities and is therefore adapted to a structure of control which combines both concentration and dispersion.

The PRC has adopted a structure of legal regulation that is better suited to the needs of our economic life and new economic structure. Article 2 of the General Principles concerning the regulation of personal and property relations between equal subjects scientifically resolves this question. According to the stipulations of this provision, and according to the statement "Concerning the Draft of the General Principles" by Wang Hanbin, Secretary of the Standing Committee of the NPC and Chair of the Legal Work Committee of the NPC Standing Committee, the salient characteristic of the Civil Code is its reflection in legal forms of the demands of the relations of the commodity economy. It principally regulates horizontal property and economic relations between equal subjects. As for the state's control of the economy, because vertical economic relations or administrative control relations between the state and enterprises and between parts of an enterprise are characterized by administrative subordination, relations with the state are chiefly regulated by economic administrative law. Therefore, the General Principles establishes the fundamentals of a regulatory system of economic law: Civil law regulates horizontal economic relations between equal subjects; economic law (also known as economic administrative law) regulates vertical economic relations in the process of economic management. The two are complementary and perform the regulatory role in the society's economic relations.

Once the regulatory system of "civil law-economic administrative law" is established, the regulatory network for China's commodity economic relations will be constituted. Regardless of what concrete form these commodity economic relations may take, they must all come under the regulatory scope of the civil law; none can violate equality or the principles of voluntariness, fairness, exchange of equivalent values, and good faith that are derived from the foundation of equality. But because we are a socialist country with public ownership as the base, the state must shoulder the responsibility of supervising, administering, and controlling civil activities. This requires the state to employ methods of economic administrative law to strengthen its administration of civil activities and to prevent the appearance within civil activities of actions that will destroy the national plan or disrupt the socialist economic order. The external integrated regulatory structure of "civil law-economic administrative law" puts socialist commodity economic relations into an ordered system.

After the establishment of our regulatory structure of economic law, neither administrative interventionist methods nor other legal regulation of a coercive character can be applied to economic relations between equal subjects. Methods of civil law must be used. Some people consider that relations formed by contracts that conform closely to the mandatory plan are 
not produced on a basis of equal voluntariness and exchange of equivalent values and therefore cannot belong to the regulatory scope of the civil law. Under the conditions of socialism, the use of the state plan means that certain contracts are directly based on the mandatory plan and that the ordered plan's targets become the subject matter and amount of the contract. The contract's subject matter and price are also fixed on the basis of the state plan's prices. But these circumstances cannot change the civil character of these contracts. Because these contracts still occur between two equal civil subjects, and because their contents are still a reflection of the relations of commodity exchange, they still are regulated by the civil law.

\section{The Fundamental Principles of Civil Activities Established by the General Principles}

In order to give full play to the civil legislation's guarantee of the citizen's and legal person's lawful civil rights, and to correctly regulate civil relations, the General Principles stipulates that various civil acts must adhere to certain fundamental principles. These fundamental principles are the starting point and basis for the formulation, explanation, implementation, and research of our civil law norms. They are also the concentrated manifestation in the General Principles of China's socialist essence.

1. The Principle of the Equal Status of Parties. The third article of the General Principles states: "In civil activities, the positions of the parties are equal." The principle of the equal status in law of all parties to civil activities is an inevitable reflection in China's civil legislation of horizontal economic relations. What the civil law regulates are the property and personal relations between equal subjects, that is, horizontal social relations. It is fixed that in civil legal relations, the legal position of the parties is uniformly equal.

The concept of the equal position of the parties contains four principal ideas. First, regardless of whether the parties' units are large or small, their position high or low, their economic power great or weak, and regardless of whether their economic character is state, collective, or individual, they occupy an equal legal status in their civil acts and are independent, equal subjects with civil rights and duties. No subject may use its own staff position, duties, or administrative influence and power to cause itself to be put in the position of a privileged civil subject. Second, civil subjects in concrete civil activities enjoy civil rights and undertake democratic duties equally. They are not permitted only to enjoy civil rights and not to undertake democratic duties or to undertake democratic duties and not to enjoy civil rights. It is not permitted for any civil subject in concrete legal relations to have special rights in excess of the law. Third, the law's protection of the civil rights of the parties is equal. Fourth, any citizen, regardless of nationality, sex, age, belief, or difference in cultural level, regardless of whether or not there has been participation in any sort of organization or undertaking of leadership 
responsibilities, and regardless of whether or not he is mentally healthy or has the ability to understand his own acts, has equal rights and abilities.

It is especially important to note that the principle of equality in civil activities is of particular significance in opposing bureaucratism and special individual privilege. Bureaucratism and special individual privilege are the remnants of feudalism and feudal ideology. Civil law is of the "innate equality school" and does not recognize any special rights. As soon as one enters into the kingdom of civil relations, that person is equal.

2. Principles of Voluntariness, Fairness, Exchange of Equivalent Values, Honesty, and Good Faith. Article 4 of the General Principles states that civil activities should conform to the principles of voluntariness, fairness, exchange of equivalent values, honesty, and good faith.

Voluntariness means that when equal subjects establish, revise, or terminate civil legal relations, both parties must of their own true will express their willingness. This is because any concrete civil legal relationship occurs between two equal subjects who enjoy independent property and personal rights. Whether or not they want to establish between them some sort of a relationship of civil rights and duties, how they should establish it, and with whom they should establish it should not only accord with legal stipulations but should also be voluntarily determined by the parties. Therefore, at the time parties carry out civil activities based on the law, other organizations and people cannot interfere with the desire of the parties or force one civil subject into committing or not committing a certain civil act. Of course, civil subjects must respect the desires of the other party at the time they exercise their civil rights and cannot damage the interests of the public or other people. To use fraud or coercion, to take advantage of another's peril, or to threaten someone's life is a violation of the principle of voluntariness; and any civil acts resulting therefrom would be without effect.

Fairness means the equality of civil subjects' opportunity to engage in civil activities, and reciprocity in the enjoyment of civil rights and the undertaking of civil duties. Each party is exposed to civil liability and consequential damages proportionate to the degree of legal violation. The principle of fairness is manifested by the economic interests between equal subjects. In judging whether a civil act is fair or not, one ought to take people's general sense of social value, concept of morality, and concept of interests as a basis. Courts have the right to void a patently unfair civil act. Nullified civil acts are without effect from the inception of the act; but if they are partially without effect, it does not influence another part which still has effect.

The so-called exchange of equivalent values means that in obtaining the other party's property or services one must provide the opposite party with an equivalent value unless otherwise provided by law or contract agreement. This principle is a legal reflection of horizontal economic relations. Commodities economic relations in essence manifest the benefit relations between equal subjects. If one side wants to realize its own interests it must 
abide by the law of exchange of equivalent values and give to the opposite party a commensurate benefit or recompense. To violate the rule of exchange of equivalent values can be harmful to ordinary civil law relations and violates the objective law of development of a commodities economy. In this matter we learned an exceedingly painful lesson during the time of the people's communes. Then, in order to achieve greater size and higher levels of collective ownership, we engaged in "reallocation without compensation." Not only did this brutally trample the principle of exchange of equivalent values, it also created an odious legacy for socialist economic development. Presently, as we uphold this principle in the midst of the economic reform, we must oppose and resist such illegal acts as the uncompensated transfer and allocation of state and collective enterprises' property, the concoction of various pretexts to impose assessments on collective and individual property, the monopolization of markets by deception, and the driving up of prices.

Honesty and good faith mean that in civil activities the subjects of civil rights ought to say what they mean, be particular about reputation, scrupulously abide by promises, not practice trickery, not pass off second-rate goods as first quality, not damage the lawful interests of the state, collectives, or individuals, and, according to the provisions of the law or contract, fulfill their civil duties. The principle of honesty and good faith also demands that at the time they carry out civil activities, parties respect habits and customs and society's public good, not evade the law, not deliberately misinterpret contracts, not misuse rights, and not engage in improper competition. Upholding the principle of honesty and good faith is both the embodiment and requirement of our socialist spiritual civilization in civil activities.

3. The Principle of Protecting Lawful Civil Rights and Interests. Article 5 of the General Principles states: "The lawful civil rights and interests of citizens and legal persons are protected by the law; no organization or individual may violate those rights and interests."

Protecting the lawful civil rights and interests of citizens and legal persons is the chief duty of our civil law. The extensive rights of property and person granted by our Constitution in politics, economics, culture, family, and other areas can be implemented only through the civil and other categories of law. In the civil law, all the civil rights and duties that may be enjoyed by citizens and legal persons as stipulated by law are within the scope of lawful civil rights and duties. These rights and duties are rather extensive, such as the right of property ownership, the right of obligation, the right of intellectual property, the right of person, the right of inheritance, the right to use state property, the right to inherit management, the right of mining, the right to manage state enterprises, and so forth. All of these are safeguarded by the law; when illegally infringed, remedy may be sought by accusation in the people's courts. No social group, including Party and state organs, enterprise, business, legal person, or social organization, can rely on its special position to violate, either directly or indirectly, the lawful civil rights and duties of another person. This basic principle of the civil law thoroughly and abundantly reflects the socialist 
essence of China's civil law, the legal embodiment of the political position of the people as masters of their own house.

4. The Principle of Abiding by the Nation's Laws and Policies. Article 6 states: "Civil activities must be in conformity with the law; where there is no provision of law, activities must be in conformity with state policy." The laws and policies formulated by the nation are the highest manifestation of the will of China's people and are the basic guideline to which all acts of every citizen and legal person must conform. Only under conditions in which every civil activity of all citizens and legal persons follows the country's laws and policies can these actions be recognized and protected, and produce the result anticipated by the parties under civil law.

In saying that civil activities ought to abide by the law, we mean not only the General Principles but also the Economic Contract Law, the Inheritance Law, the Marriage Law, the Trademark Law, the Patent Law, and other discrete civil enactments, as well as the Constitution and other laws, such as the Criminal Law and the Code of Civil Procedure. The legality of behavior is a basic demand that the law places on civil activities. If one does not respect the law, then a civil activity cannot normally be carried out; and the interests and rights of other people are damaged.

Because of the breadth and complexity of civil activities, the stipulations of the law cannot be without omissions. Moreover, the reform of our urban economic system is ongoing, and for many problems provisions cannot be produced immediately. In these circumstances we must follow national policies. If civil activities violate the law or national policy, then one must bear the burden of either civil or other legal responsibility.

5. Civil Activities Must Observe Social Morality, and Must Not Damage the Collective Interests of Society, Wreck the State Economic Plan, or Disrupt Social Economic Order. To respect social morality and abjure from injuring society's collective interests are the common criteria with which all activities in a socialist society must comply as well as the ideal to which all civil activities must conform. Our economy is a planned commodity economy based on public ownership, and this determines that civil activities cannot wreck the state economic plan or disturb the economic order of society. In particular, economic contracts between legal persons cannot disregard or violate the state's mandatory plan. Otherwise they are without effect.

4. The General Rule Concerning Commodity Economy Activities Established by the General Principles. The commodities economy is an economic stage that succeeds the natural economy and that cannot be skipped. A civil law that regulates the relations of a commodities economy is from beginning to end an accompaniment and adaptation to the commodities economy. Thus, the entire history of the civil law is the history of the development of the commodities economy, and civil law norms are nothing more than a reflection of the internal demands of the commodities economy. Engels has stated that 
civil law principles are but the expression in legal form of the conditions of economic life in a society. The General Principles elevates the internal laws of the socialist commodities economy to the level of legal norms, thereby establishing a common rule of conduct to be observed in activities of the commodities economy.

First, the General Principles affirms the equal legal position of the subjects of commodities exchange. As Marx pointed out in Das Kapital, commodities are things without will and cannot take themselves to the market to be exchanged. ${ }^{4}$ If one wants to have reciprocal relations occur between commodities, it must occur through the expression of one's desire to the guardian or owner of these commodities. In civil law the commodities' guardian or owner is the subject of civil rights. The establishment of the system of subject makes it feasible to protect the legal interests of the producer and manager of commodities, and to stabilize the order of routine exchange. Commodities exchange is a sort of free transaction between parties of independent will. "The circulation of commodities differs from the direct exchange of products (barter), not only in form, but in substance." 5 Consequently, civil law rejects administrative compulsion and demands that no distinction be made between organizations and individuals, between ministries and regions. The subjects of civil rights are equal in civil legal relations. Article 3 of the General Principles provides: "In civil activities, the positions of the parties are equal." This then is not only a rejection of the system under the old structure in which a system of direct control was implemented by administrative interference in commodities exchange but also an advocacy and protection under the new structures of the development of economic ties between equals. The current process of moving from the old to the new system is fraught with contradictions and clashing explanations. But without legal protection of equality, we cannot have mutually beneficial and voluntary associations. Horizontal economic linkages cannot reach their proper development. Thus the equality of the subjects of civil rights is a general requirement for carrying out commodities exchange.

Next, the General Principles affirms the ownership or management rights of commodities production. The core duty of our urban economic reform is to increase enterprise vitality and to develop the socialist commodities economy. This duty requires of the law that it supply a powerful guarantee of the realization of this central duty. The key is that it must affirm the right of ownership or management of commodities production. In regard to the state enterprise, ownership is to be separated from management. The measure of the ownership right that is the management right is to be severed and given to the enterprise, thereby transforming the enterprise from an administrative creature into a relatively independent commodities producer, one which of its own will can free itself from bureaucratic and territorial restraints and rapidly develop horizontal economic ties. Adapting to this need of the economic

4. Special Editor's note: I K. Marx, Capital 84 (1967).

5. Special Editor's note: Id. at 112. 
structure, article 82 states: "The right enjoyed by a state-owned enterprise to operate according to law state property that has been given to it to operate and manage is protected by law." Thus, the state enterprise has a legally defined scope of rights to possess, to use, to benefit from, and to dispose of the property entrusted to its management and control by the state. Unless provided for in law, no unit or individual may interfere. The ownership right or management right is the precondition for the enterprise to devote itself to commodities exchange. The free use of this sort of right under conditions in which the interests of neither society nor other persons are harmed is a general rule of commodities exchange.

Third, the General Principles establishes the legal form of commodities exchange-namely the contract system. In its present form, China's socialist system of public ownership is expressed in two basic shapes, ownership by the whole and collective ownership. In addition, the individual economy still exists as a necessary supplement to the collective economy. Whether between units of different or identical ownership forms, economic linkages must be carried out in the form of contracts with consideration. Under the traditional economic system, because forms of ownership other than state ownership were deprecated, the independent interests of enterprises as commodities producers were seized and redistributed without compensation. The administrative plan displaced the contract system. With the economic reform all forms of ownership have developed abundantly, and the material interests of units of the same ownership system have also been respected. Therefore, commodities transfer is substituted for commodities exchange and the contract system begins to play a role. Article 85 of the General Principles states: "A contract is an agreement whereby parties establish, modify, or terminate civil legal relations. Contracts formed in accord with law are protected by law." Thus, the contract system has been adopted to supply effective legal protection to the process of developing horizontal economic ties in our country.

\section{IV}

The Role of the General Principles in the Reform of the ECONOMIC System

What strikes the world about China's reform of the economic system is that its essence is the development of a socialist commodities economy. A commodities economy is the unification of commodities production and commodities exchange. Commodities exchange is a system of never-ending circulation and uninterrupted development. Various forms of exchange perdure while new ones arise, inevitably demanding the protection of a civil law characterized by equality and equal value. Indeed as Marx noted, "Whenever industrial and commercial development produce new forms of 
exchange, the law cannot but recognize them as a new type of property." 6 Following the reform of our economic system and the development of the commodities economy, we must extend the scope of our civil law and stress the position and role of the civil law in regulating all aspects of commodities relations in the sector of circulation. The chief uses of the civil law in China's economic reform will be discussed below.

\section{A. The Civil Law Affirms and Safeguards Various Rights of Economic Organizations and Citizens}

Historically, the civil law norm adopted vigorous methods to confirm and safeguard existing economic ties. The General Principles also does this. However, the General Principles is not a summation of the discrete experimental results of economic reform, but is rather an abstraction of the rules of inevitability and inherent limitation of cause and effect that exist beneath the surface of the economic reform. Therefore it already is not an idea concerned with the general confusion, but a rich totality possessed of numerous definitions and relations. This sort of ideal in the General Principles is reflected in the civil rights of its subjects. It recognizes and protects the civil rights of the numerous and various exchangers of commodities described below.

1. The Legal Person. The legal person is an important form in traditional civil law. Since the German civil law first established this type of economic organizational form, every country's civil law has subsequently followed suit. China's stipulations on the legal person have certainly borrowed from the enactments of foreign countries, but the Chinese character is still perfectly clear. ${ }^{7}$ First, it makes the enterprise legal person a sort of independent legal person, and in this way breaks the discrete categories found in foreign civil legislation between the public and private legal person, between the social group legal person and the financial group legal person, and between the state legal person and the collective legal person, and provides clear direction for the organizational reform of our companies' administrative character. Second, it stipulates the property scope for which the ownership-by-the-whole enterprise legal person undertakes responsibility, namely the property entrusted to its operation and management by the state, thereby legislatively affirming the independent property rights and responsibilities of the ownership-by-the-whole enterprise legal person. Third, on the basis of the first principle, it affirms the phenomenon of bankruptcy. Bankruptcy is the inevitable consequence of fierce competition in a commodities society, though nations with collective systems of ownership often do not want to face up to this fact. In responding to the needs of advancing economic reform, the General Principles clearly stipulates that the enterprise legal person can be

6. Special Editor's note: See The German Ideology, in R. Tucker, The MarX-Engels Reader 188 (2d ed. 1987).

7. Special Editor's note: But cf. Epstein, The Theoretical System of Property Rights in China's General Principles of Civil Law, Law \& Contemp. Probs., Spring 1989, at 177, 178. 
terminated through the declaration of bankruptcy. In the civil legislative history of public ownership in this country, this is an innovative stipulation.

2. Joint Operation. Joint operation is when two or more than two economic organizations organize a horizontal economic association in order to obtain a common economic goal. It can be a union between similar forms of ownership, or it can be a mutual infiltration by different forms of ownership. Joint operation is something of vitality that has emerged from our economic reform. It is one of the essential forms in the development of our commodities economy, of benefit in destroying localism, improving the circulation of commodities, expanding the exchange of economic technology, and promoting the rationalization of enterprise organization.

In order to protect and encourage its development, the General Principles made special provisions for joint operation, which, based on the degree of tightness of joint operation, may be divided into three situations. First, all newly organized economic entities that possess the conditions for a legal person may obtain the qualification of a legal person and independently assume civil liabilities. Second, all joint operations that do not possess the conditions for a legal person may, either on the basis of the proportion of capital invested by each of the joint operators, or, through agreement, with each side's own property, undertake civil liability; but if the law or the agreement so provides, joint operations must undertake joint and several liability. Third, if according to contractual agreement each operates independently, then each assumes its own civil liability. At present, in the midst of the process of encouraging and developing horizontal economic associations, regardless of which of the three forms is adopted, parties to the association must abide by the principles of equality, mutual benefit, and voluntariness. Supervising units cannot give orders like a parent or run things by themselves without consulting the parties. At the same time, the shape of each parties' rights, duties, and liabilities must be clarified, the regular order of the circulation of commodities safeguarded, and the legal rights and interests of creditors and both parties to the association protected.

3. Rural Contract Management Households, and Individual Commercial and Industrial Households. Throughout rural areas, after the widespread implementation of two types of family linked production contract responsibility systems-output responsibility (baochan) and full responsibility - the position and role of the rural management household in the economic activities of society have received special attention. The party and the state have already established and perfected the systems of production responsibility and full responsibility. The encouragement and support of rural households' development of commodities production is a long-term policy. But in the past the question of whether or not the rural household becomes a subject with rights and duties in civil law had not been resolved. Article 27 of the General Principles provides: "Members of rural collective economic organizations who in accordance with the provisions of a 
contract conduct business with respect to goods within the scope permitted by the law are rural contract operation households." This fundamentally resolves the legal position of households which undertake operational responsibility. It makes them a subject with rights in civil affairs. The household with contracts for operation can, on the basis of the law, undertake production management activities, and the law protects its lawful rights and interests against violation. Concerning the individual industrial and commercial household, article 26 of the General Principles provides: "Citizens who, upon approval and registration in accordance with law, conduct industrial or commercial business within the scope permitted by law are private industrial/commercial households. A private industrial/commercial household may have its own trade name."

4. Individual Partnerships. Partnerships are a form of economic organization in a commodity economy. Since the Third Plenum of the Eleventh Party Congress, an array of economic organizations with partnership characteristics has appeared throughout our cities and villages. In this sort of organization, property is under the unified control and use of the partners. There is collective management, collective labor, and division of the returns and liabilities. But because there were previously no legal provisions for a partnership system, the legal status of partnership was unclear, as were the internal and external responsibilities of partners, so that conflicts were relatively common. Our General Principles made special provisions in regard to individual partnerships and moreover insisted that unless the law provides otherwise, partners must undertake joint (and several) liability for debts.

5. Citizens. To be a citizen who is a civil subject is to enjoy rights in civil affairs and to undertake the duties in civil affairs of a natural person. Based on the provisions of the General Principles, our citizens enjoy broad rights in civil affairs. In respect to property rights, citizens enjoy the right of individual ownership, the right to administer and use collective property, the right to be recompensed for labor, the right to inherit property, the right of patent, the right to trademark, and others. In terms of the rights of the person, citizens enjoy the right to life and health, the right to one's name, the right to one's likeness, the right to one's reputation, the right of free marriage, the right of authorship, the right of discovery, and so forth. The civil rights of our citizens are uniformly equal, and cannot, except by law, be restricted or eliminated. Anytime a citizen's rights are infringed, the citizen can seek protection from the people's courts. In China, rights and duties are united, so that citizens must undertake appropriate civil duties at the same time they enjoy civil rights. It is impermissible to damage the interests of the state, the collective, or of other individuals in carrying out one's rights. 
B. The General Principles' Affirmation of the System of Ownership and System of the Enterprise Legal Person is an Effective Method of Properly Maintaining the Balance Between the State and the Enterprise and of Strengthening the Vigor of the Enterprise

A survey of the world's modern civil codes shows that the systems of ownership and legal person are the core of their contents. The system of right of ownership is the legal reflection of ownership relations and is the inner link with commodity relations. The process of the exchange of commodities demands of law that it clarify in whom property is vested because the essence of commodities exchange is the yielding of the right of ownership. The right of ownership is the prerequisite for and the result of the production and exchange of commodities. Whoever enjoys the right of ownership is the person who enjoys the legally established right to possess that property. Article 71 of the General Principles stipulates: "Ownership means an owner's right in accordance with law to possess, use, benefit from, and dispose of his own property." This reveals from a legal point of view the connotation and character of the right of property ownership.

In China's General Principles, the right of property ownership is one of the most vital rights in civil affairs. Because China's socialist collective system is expressed in the two basic forms of ownership, ownership by the whole and collective ownership, the General Principles appropriately affirms these two systems of ownership.

Article 73 of the General Principles states: "State property belongs to all the people." In the present circumstances, property owned by the whole means that the representative of all the people-the state-occupies the property and exercises the right of ownership over it. Therefore property owned by the whole can also be called state property. In our country the right of ownership by the whole has the following features:

1. Ownership by the Whole is Exclusive and Unified. The exclusive character refers to the fact that the subject of the ownership right is only one person, that is, the state. Other than the state, no organization or individual can become the subject of the right of ownership by the whole or with the state jointly become the subject of the right of ownership by the whole. The unified character refers to the fact that legally the state unites the control and exercise of the right of ownership by the whole. But this does not signify that all property owned by the whole can be directly administered and operated only by the state or government organizations. The state can, through law or direct authorization, convey operation and administration of property of the whole to enterprise and business units.

The object of ownership by the whole is of unlimited breadth. That is, any property can become the object of ownership by the whole. Based on the provisions of the General Principles, some property can be owned only by the whole, such as minerals, water, cultural artifacts beneath the soil, historical 
relics, wild animals, and so forth. Some enterprises, businesses, and installations of vital relation to the national well-being, such as the postal service, military industries, military installations, railways, airline facilities, etc., are also owned solely by the state. In addition, the state also may, based on society's collective interests and needs, from time to time by law or orders proclaim that certain property belongs to all the people, such as the twentytwo nature preserves established by the plan, or the establishment of national parks.

The law provides strong protection for ownership by all the people. Article 73, section 2, of the General Principles stipulates: "State property is sacred and inviolable: It is forbidden for any organization or individual to interfere with possession or to loot, secretly divide up, divert for personal use, or destroy [it]." Any conduct that violates ownership by all the people must be punished by the law.

Article 74 of the General Principles provides: "The property of collective organizations of the working masses belongs to the working mass collective."

a. Ownership by the working mass collective is another Chinese form of collective ownership. Those working mass collective organizations that are legal persons include urban collective economic organizations, village peasant collective economic organizations, and township collective economic organizations. All of these organizations are independent subjects of rights in civil affairs which independently exercise the right of property ownership on their own authority and may possess, use, benefit from, and dispose of property, without the illegal interference of or violation by any organization or individual.

b. The object of working mass collective ownership is fairly broad. It includes that land legally stipulated as collectively owned: land and forests, mountains, grasslands, wasteland, shoreline, and so on; the property of collective economic organizations; collectively owned buildings, reservoirs, agricultural irrigation facilities, and educational, scientific, cultural, health, and sports facilities, as well as all other collectively owned property. Beyond this, the General Principles stipulates that collectively owned land belongs according to law to the village collective and is operated and managed by agricultural collective economic organizations such as village agricultural production cooperatives or the village committee. Land already owned by the township peasant collective economic organizations can belong to the township peasant collective.

c. Working mass collective ownership is strictly protected by law. Article 74, section 3, provides: "Collective property is protected by law. It is forbidden for any group or individual to interfere with possession, or to loot, secretly divide up, destroy, or illegally impound, sequester, freeze, or confiscate it."

The ownership system provided by the General Principles not only affirms the status of the state and the collective as, respectively, subjects of the 
systems of property ownership by all the people and by the working mass collective, it also provides forceful legal protection. Furthermore, in the course of reform of the economic system it balances state and enterprise relations and gives direction for the invigoration of enterprises that is part of the reform of the economic system.

The enterprise legal person is an extremely important subject of civil rights. Under our socialist conditions, the system of enterprise legal person is an efficacious organizational form that takes an enterprise which is engaged in the activities of a commodities economy and sets it on a course of legality; it concentrates capital to initiate large-scale economic construction and develop science and technology. Article 36 states: "Legal persons are organizations that have civil capacity, are competent to perform civil acts, and according to law independently enjoy civil rights and assume civil duties." Articles 41 to 49 contain various concrete provisions on the enterprise legal person. Thus the forms of the General Principles formally establish the legal status of the enterprise legal person. These provisions in the General Principles are responses to the need to strengthen enterprise vitality in the course of economic reform and in turn provide the legal guarantee for the invigoration of the enterprise.

The Third Plenum of the Twelfth Party Congress pointed out: "To strengthen enterprise vitality, to strengthen large- and medium-scale enterprises owned by all the people is the key link in the reform of the urban economic structure." But if we are fully to invigorate enterprises, then it is essential to cause them truly to become relatively independent objects, to achieve self-control, and to become socialist commodities producers and operators that take responsibility for gains and losses, that is, in the final analysis to become legal persons that have fixed rights and duties. This point is something that was truly overlooked before reform.

Before reform, our urban economic system's defect was in its emphasis on implementing the plan's control over enterprises and in ignoring the enterprises' relatively independent position, as if the state's control over enterprises meant the deader the better. In this sort of situation, state ownership could not be separated from the right of operational control and led to the state using administrative methods to interfere willfully in the enterprises' horizontal economic activities, substituting the desires of senior officials or administrative orders for the law of value in commodities exchange. Not recognizing that each enterprise had its own material interests and not recognizing that the means of production are a commodity meant that the production responsibility of enterprises owned by the whole were transmitted downward by the state, goods were distributed by the state, personnel were assigned by the higher levels, equipment was allocated by the state, all profit was sent upward to the state, and losses were the responsibility of the state. In this way, enterprises became nothing more than branch organizations of this large enterprise, the state, and possessed none of the qualifications of an independent legal person. Within, they lacked vitality. 
Without, they lacked force. They were bereft of the life that an economic organization ought to have.

The system of enterprise legal person creates an appropriate separation of ownership and operation/management, an excellent organizational form for stimulating the invigoration of the enterprise. Article 82 of the General Principles states: "The right enjoyed by a state-owned enterprise to operate, according to law, state property that has been given to it to operate and manage is protected by law." This is the first legislative confirmation of the separation of the enterprise legal person form of ownership and of the separation of ownership and operation rights. The subject of the enterprise property ownership right is the state; the subject of the right of operation is the enterprise. In Chinese socialism, the right of operation is the core of the system of economic management. The vesting of the right of operation is the most important indicator of the direct expression of the nature of the system of economic management. Only if the divorce of state ownership from enterprise operation is effected can the enterprise truly be granted the status of a legal person.

The operational right of the legal person is a new type of right that is assigned from and is separated from the body of the state's ownership rights. In terms of its nature, it is a sort of independent "real right," or right over things, and includes the various civil rights that commodities producers and operators ought to enjoy. Not only can it, based on law, resist any person, including the owner, but through the exchange of commodities there may also occur the acquisition and transfer of the right of ownership of state property. Because the enterprise possesses the operational right, it enjoys the right to possess, use, receive benefit from, and dispose of property according to law.

In horizontal relations of exchange, the transfer of property between enterprises is conducted through forms of commodity exchange. Protective methods may be used to protect ownership rights against unlawful violations and compensation demanded. In administrative regulation of vertical and horizontal relations, the operational rights of the enterprise are strictly safeguarded and cannot be subjected to any extra-legal interference. If because of administrative supervisory organizations' mistakes, the enterprise operation suffers a loss, the administrative organization must undertake the appropriate liability. In sum, the General Principles' establishment of the enterprise legal person's operational right is of help in stimulating the enterprise to win over various benefits in the course of operational management and of help in making clear that the enterprise is liable for bankruptcy if its operational management is poor and its losses accumulate to a certain level. Therefore, the enterprise legal person plays an extremely important role in motivating and invigorating the enterprise, which is the heart of the reform of the urban economic structure.

2. The General Principles' Provision of a Contract System is the Fundamental Link in the Establishment of a Unified Socialist Market System. According to Marx's theory of labor value, the value of commodities set by socially necessary labor- 
time and measured in commodity-currency relations is expressed as price. Under the influence of supply and demand, price revolves around the fluctuations of value, thereby leading to a generalized competition between operators. This sort of competition demands the removal of all obstacles to competition, so that it becomes a unified market system. If there is no unified market, it can become only a sort of stunted commodity economy. To become a smoothly functional unified market, it is necessary to assist the reflection of the law of commodity economy, and to carry out administration and adjustment through forceful rules. The contract system is precisely this sort of rule in legal form of commodities exchange in a unified market, and also becomes an essential legal guarantee of the unified socialist market. In this regard, article 85 states: "A contract is an agreement whereby parties establish, modify, or terminate civil relations. Contracts formed in accordance with law are protected by law."

A system of unified socialist markets includes a commodities market, a labor market, a capital market, and a technology market. Regardless of the type of market, the principal subject of the circulation is the enterprise; regardless of the type of market, the buying and selling of objects must conform to the law of value and be conducted in accordance with the principles of exchange of equal value and mutual equality. The general concept of contract established in the General Principles and the concrete provisions in the Economic Contract Law regarding these four types of market are a high level ideal and generalization of the law of circulation. They provided the legal standing and requirements of the enterprise as the subject of market circulation at the time it signed agreements, stipulated the subject matter and price of the contract, and defined certain conditions for a contract to have effect. Experience proves that an enterprise can avoid being forced into contractual relationships by administrative fiat only if it voluntarily selects partners with whom to deal, can agree on mutually acceptable contract terms achieved through negotiation, willingly accepts contract terms as binding and enforceable, and accepts the fundamental principle of equal exchange. By emphasizing the relatively independent interests of the enterprise, the localism and departmentalism of the past which severed horizontal linkages within the economy can be changed and suitable cooperative relations of division labor can be established.

Using the contract system to establish and regulate a unified socialist market system, we must adhere to the following principles.

a. Equality of mutual benefit, and exchange of equal value. As the subject of market circulation, relations between enterprises must be relations between equal subjects. Thus, despite belonging to different administrative spheres or having different ownership regimes, once they enter the marketplace, all enterprises are in an equal legal position. They ought to regard their opposite as an equal owner or exchanger of commodities, and in obtaining the opposite's commodities, labor, capital, or technology must pay the actual 
value in money or in other forms of compensation permitted by law. (This principle has already been discussed so the remarks here are brief.)

b. Abiding by the principle of protecting the enterprise's independent interests. The enterprise is an economic organization characterized by profit, which has its own material interests. The source of the enterprise's interest is in its independent management, and it may freely allocate and dispose of its property within a fixed scope. Its interests are the source of the enterprise's impetus. In the marketplace, the enterprise has the right to protect its own lawful interests, and other subjects have the duty to respect and not to violate the enterprise's interests. Thus can we objectively encourage the stability and prosperity of the unified socialist market. On the other hand, we can further stimulate the interest motive of the enterprise, thereby invigorating its operational management. First, the enterprise acts as the independent subject intended by law; in order to protect its own "character" and reputation in the market, it must demand that all of its members strengthen the sense of being master of their own affairs, continuously advance industrial technology, improve product quality, create high-grade products and firstclass trademarks, and compete successfully against foreign goods. Second, the enterprise participates in economic circulation with its own property or with that which it operates and manages, thereby fostering its focus on market news, strengthening its ability to meet an emergency and reduce or avoid economic loss. Third, in order to protect its own economic interests in the market, the enterprise must completely fulfill its duties under the state plan and continuously improve its operational and management level and economic benefit, independent accounting, and responsibility for profit or loss. It must also emphasize contract, receive credit, and exercise its right to resist and file suit against all violations of its interests. In this way, the prosperous development of the socialist unified market is objectively encouraged and its good working order safeguarded.

c. Uphold the principle of the enterprise independently assuming responsibility for property. Since the enterprise manages itself and takes sole responsibility for profit and loss, it possesses independent economic interests and property. Thus, at the time of market movement, it ought to undertake property obligations independently. This obligation includes consciousness of violation or failure to implement contracts and concurrent responsibility for compensation. It also includes accepting the consequences that bankruptcy carries with it. In this regard, article 48 states clearly: "A state owned enterprise legal person bears civil liability to the extent of the property the state has given it to operate and manage. A collective enterprise bears civil liability to the extent of the property the enterprise owns. Civil liabilities of a collective enterprise shall be satisfied from the assets the enterprise owns. Sino-foreign joint venture enterprise legal persons, Sino-foreign contractual joint venture enterprise legal persons, and wholly foreign-owned enterprise legal persons bear civil liability to the extent of the property the enterprise 
owns, unless the law provides otherwise." This provision is the first clear differentiation of the scope of property for which the enterprise undertakes civil liability. Consequently, for the enterprise, especially the state enterprise, it means an end to the psychology of the Cultural Revolution period. No longer can enterprises ignore whether or not a task is completed or performed well. No longer can they simply relegate losses and debts to the state. Elsewhere, the civil law also stipulates that the enterprise can be ended because it has been declared bankrupt. In 1986 the NPC passed the Bankruptcy Law, which became effective in 1988. This further clarified the property obligations of the enterprise in market exchange. Owing to the role of the law of value in market exchange, inevitably some enterprises profit while others suffer losses. When the losses reach a fixed proportion of the net worth of that enterprise's property, it can become bankrupt. Legally speaking, bankruptcy occurs when the debtor's entire property is insufficient to meet its obligations and the creditor is forced to employ procedures of litigation determined by law to obtain full payment. Bankruptcy is the elimination by competition of the less advanced and less efficient, an effective mechanism for motivation, and of enormous use as a spur to the enterprise legal person. Therefore, to uphold the principles of the enterprise independently assuming debt and the consequence of bankruptcy is advantageous to the encouragement of fair competition in a flourishing socialist market. 
. 